\title{
15. DEEP-SEA FAN DEPOSITS FROM TOYAMA TROUGH, SEA OF JAPAN
}

\author{
Arnold H. Bouma, Department of Oceanography, Texas A\&M University, College Station, Texas
}

\begin{abstract}
Sediments from the Toyama Trough and adjacent Yamato Basin have always been considered to be turbidites. The 527 meters of sediment cored at Site 299 during DSDP Leg 31 can be interpreted as such although the deposits do not reveal great similarity to described distal turbidites. It is better to describe these sediments as submarine fan deposits, consisting primarily of levee and overbank deposits and possibly some channel sediments.

The complexity of minor lithological variations with primarily thin and thick laminations, graded bedding, and some possible microforeset bedding, suggests a submarine fan area with a small sediment size (and/or poor in sand), frequently shifting channels, broad levees, and extensive overbank areas.

Coring distortion makes it impossible to develop various sedimentary models for the different subenvironments, except for the uppermost cores which are interpreted to be from outer levee and proximal overbank deposits. This model shows some lamination at the bottom in slightly sandy material. Graded bedding changes this sediment into a very silty clay, followed by a silty clay, grading into a clay. Increase of pelagic fossils can be observed in the same direction. This model presumably cannot be used to interpret fossil sediments unless it has been determined that they belong to a submarine fan complex.
\end{abstract}

\section{INTRODUCTION}

Site 299 of DSDP Leg 31 was located close to the axis of the Toyama Trough in the southeastern Sea of Japan (Figure 1). This trough forms part of the Yamato Basin or Honshu Deep Basin located between the central northwest side of the island Honshu and the Yamato Rise (Kaseno, 1972). The Toyama Trough starts in Toyama Bay, an embayment bounded by Honshu and Noto Peninsula (Niino, 1952). Its axis first trends to the northwest after which it turns to approximately north (Terada, 1934). The channel axis is slightly winding and cross sections reveal its submarine canyon/fan valley nature, terminating in a deep-sea fan (Shepard and Dill, 1966; Hilde et al., 1969; Hilde and Wageman, 1973). Levees can be clearly distinguished along the convex sides of the channel curves. Hilde et al. (1969), Hilde and Wageman (1973), Kaseno (1972), and Ludwig et al. (in press) stress the importance of this trough to turbidity current deposition. Often it is not clearly indicated whether the sediments in the Toyama Trough are turbidites, submarine canyon/fan valley deposits, or submarine fan sediments. Kaseno (1971) distinguished twelve distinct phases based on tectonism, volcanism, sedimentation, and paleogeography in the coast region of Japan.

Site 299 was drilled at $39^{\circ} 29.69^{\prime} \mathrm{N}$ and $137^{\circ} 39.72^{\prime} \mathrm{E}$ at a water depth of 2599 meters (Figure 1). Although practically all cores were moderately to heavily disturbed by the coring action, portions allowed good observations. Section 1-6, a punch core, was only slightly disturbed and provided a good description that served as the base for the description of other cores from this hole. In the core description (Site Report, Chapter 10, this volume) it is suggested that two interpretations can be defended. The most likely interpretation refers to an alternation and succession of channel, levee, and overbank deposits belonging to a submarine fan complex. The other interpretation points to nearby (proximal), and distant (distal) turbidites. The possibility exists that some distallike turbidites have been deposited within the submarine fan system, thereby presenting a combination of both interpretations.

\section{DATA GATHERING AND SAMPLE PREPARATION PROCEDURES}

As soon as the plastic liner was split lengthwise, the core was cut using a wire, knife, hacksaw, bandsaw, diamond saw or an electro-osmotic knife, depending on the type of material and the degree of consolidation/lithification. The upper cores were split with an electro-osmotic knife which allows easier cutting, and resulted in a clean, nonsmeared sediment face (Chmelik, 1967; Bouma, 1969). After visual observations and core descriptions were made, a $40-\mathrm{cm}$ part of the working half could be selected for more detailed observations. The details of the sample preparation are discussed in Chapter 14 , this volume.

In the laboratory, the sample slice was X-ray radiographed using Kodak Industrial X-ray film type AA. Contact prints were made of the radiographs and the black and white negatives enlarged to original size.

The sample slices, radiographs, and photographs were used for a detailed description of lithology, sedimentary 


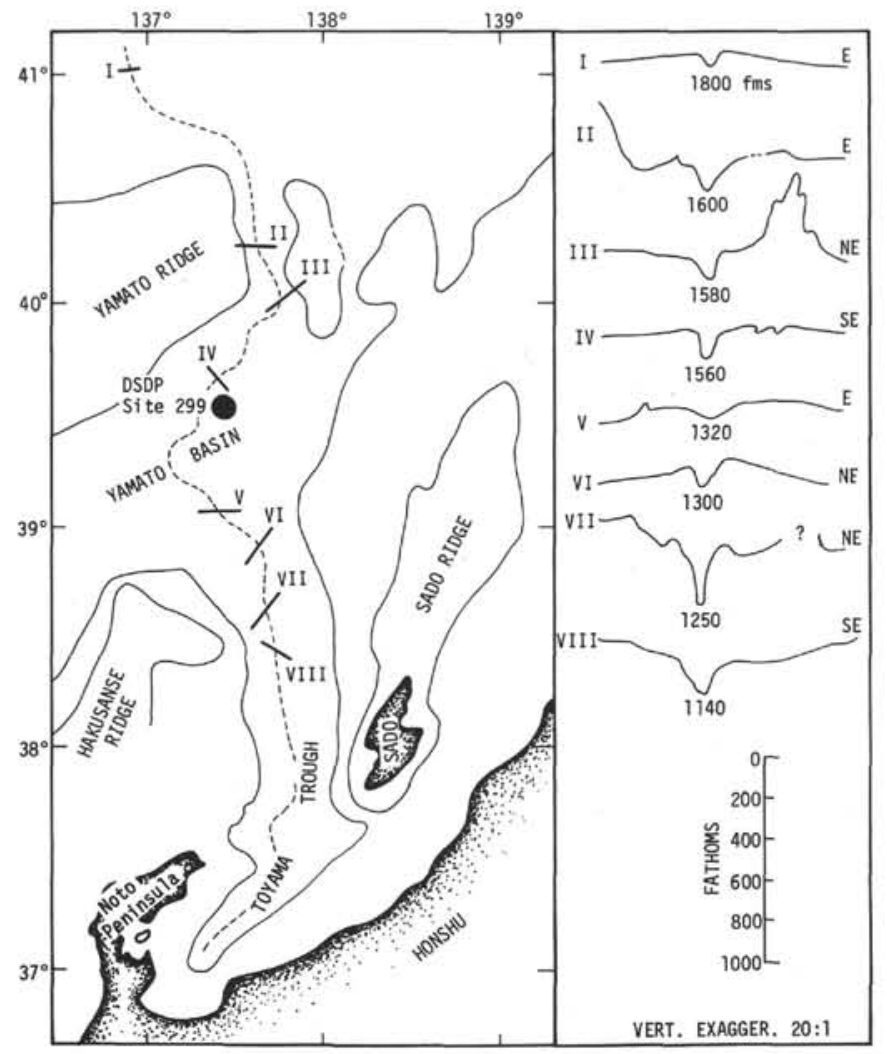

Figure 1. Simplified physiography of the Toyama Trough and Yamato Basin area. The location of Hole 299 is close to cross section IV. The shape of the cross sections indicates submarine fans rather than abyssal plains. (Redrawn after Hilde et al., 1969; Kaseno, 1972; Ludwig et al., in press).

structures, and color. A number of smear slides were prepared to aid in the textural and compositional description.

\section{SAMPLE DESCRIPTIONS}

\section{Core 1, Section 6}

Two slices from Core 1, Section 6 were selected for a detailed description. They represent a prototype for parts of the sedimentary column at this site. Figures 2 and 3 contain photographs and prints of radiographs, while Figure 4 shows a semigraphic illustration of the major part of this section. The main characteristic of this deposit is the layering made visible by color and/or lithologic variations. The dominant lithology is a silty clay with varying amounts of silt, while a few clay layers, sandy silts, and volcaniclastics were observed.

The rather general intense coring distortions made it difficult to obtain enough reliable and successive information to clearly recognize sedimentary cycles. Detailed studies indicate that the most likely cycle for the upper eight cores is the one presented in Table 1 (see also lithologic description of Site 299 Chapter 10, this volume). A general upward decrease of grain size (graded bedding) with parallel lamination at the base are the only observable sedimentary structures. The contacts between the lithologic divisions within the cycle vary from distinct to very vague.

The thin and thick parallel laminae vary not only in distinctness, but also in regularity. Some of the irregular laminae may be artificially (coring operation) induced, others seem to be sedimentary in nature. The contact at $80 \mathrm{~cm}$ presenting horizontal, irregular, parallel laminae cut off by dragged down, indistinct, and very irregular laminae, is most likely a result of coring rather than being sedimentary in origin. The complexity of contacts and color/lithologic changes between 36 and $39 \mathrm{~cm}$ also represent (in part) coring distortions.

Smear-slide examinations reveal high silt percentages. A number of smear slides from other cores from this site were compared to DSDP grain size analyses for calibration, primarily to find out if the sand/silt-size particles, (composed of clay-size material and fine silt), are original fragments or just lumps on the smear slide that were not disintegrated during slide preparation. The comparison shows that the sand/silt lumps are hard, and since they occur very close to the water-sediment interface, diagenesis can be excluded. It is concluded that these "rock fragments" are the result of a previous transport-deposition cycle, and were transported to the present area as sand/silt fragments. No detailed quantitative petrographical analyses were made. Semiquantitative compositional data is given in Figure 4.

\section{INTERPRETATION OF OBSERVATIONS}

The sedimentary cycle, as presented in Table 1 , is characteristic for the upper eight cores from Site 299. To a certain extent the cycle can be observed in some of the deeper cores from this hole, but coring disturbances prevent accurate and continuous observation.

Although the sediments from this area of the Sea of Japan have been interpreted as turbidites by other authors, no real comparison can be observed to the distal turbidites as described by Bouma $(1972,1973)$, Piper (1973), and Bouma and Hollister (1973). The location of the site, as well as the sedimentary characteristics, makes an interpretation of submarine fan deposits more likely. Detailed descriptions of such environments are discussed by several authors and summarized by Nelson and Kulm (1973).

The lack of sand in most of the cored sedimentary section at this site has four possible interpretations) (1) lack of sand in the source area, (2) a narrow confinement of sand in channel axes thereby decreasing the chance of coring a good mid-channel section, (3) lack or no recovery of such sands, and (4) bypassing of most sand to the adjacent abyssal plain. Dealing with only one drill site prevents the determination of the correct interpretation.

A deep-sea fan area is composed of shifting channels with levees and overbank deposits (Nelson and Kulm, 1973). From the apex to the periphery, a continuous bifurcation of channels occurs, resulting in more channels which become shallower and smaller in size. These channels do not significantly increase the total cross-sectional size of the original channel(s) that exist near the apex. Levees are often broad and low. In many 

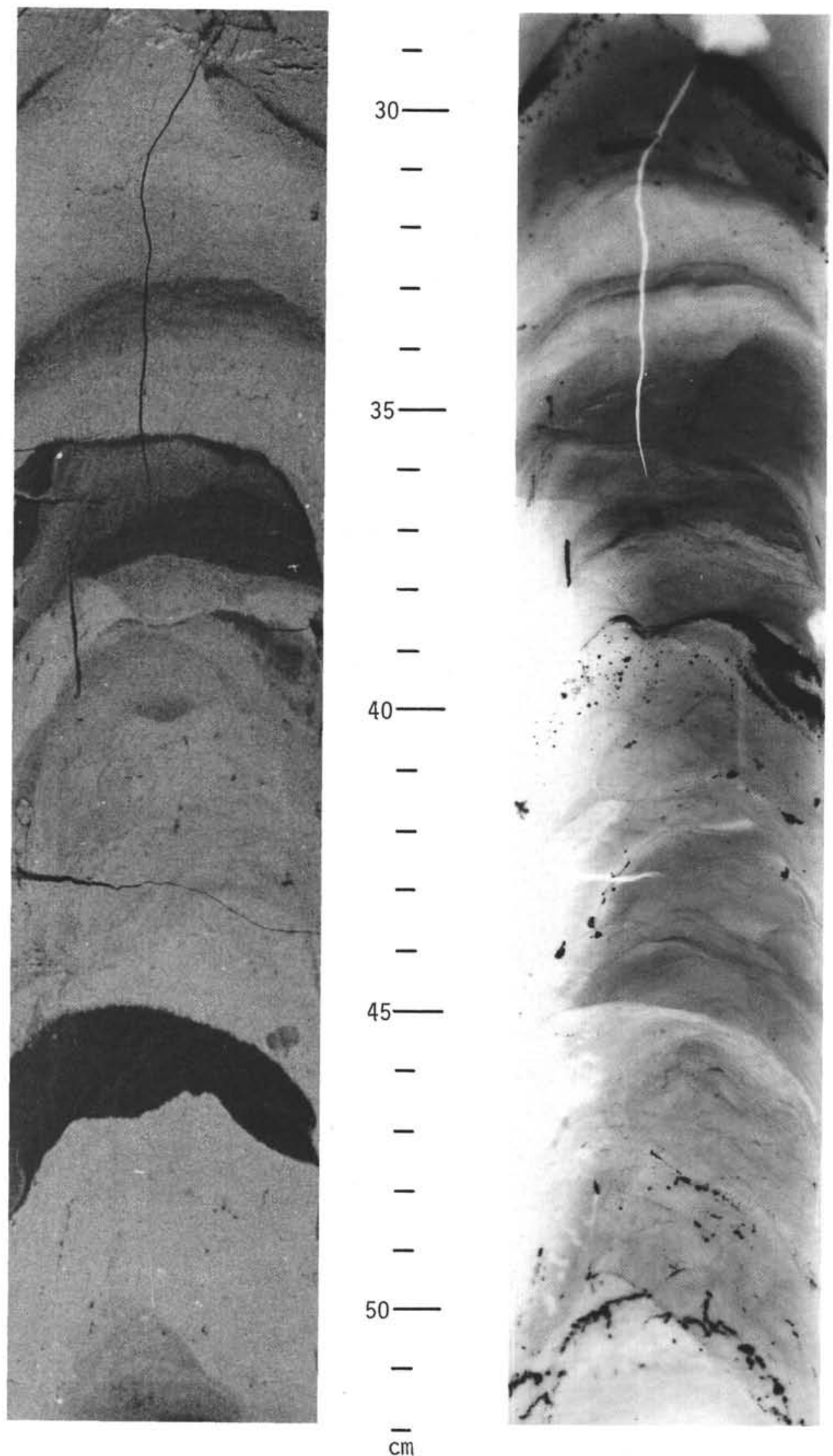

Figure 2. Photograph and print of radiograph from a sediment slice from Sample 299-1-6, 29-52 cm. 
A. H. BOUMA

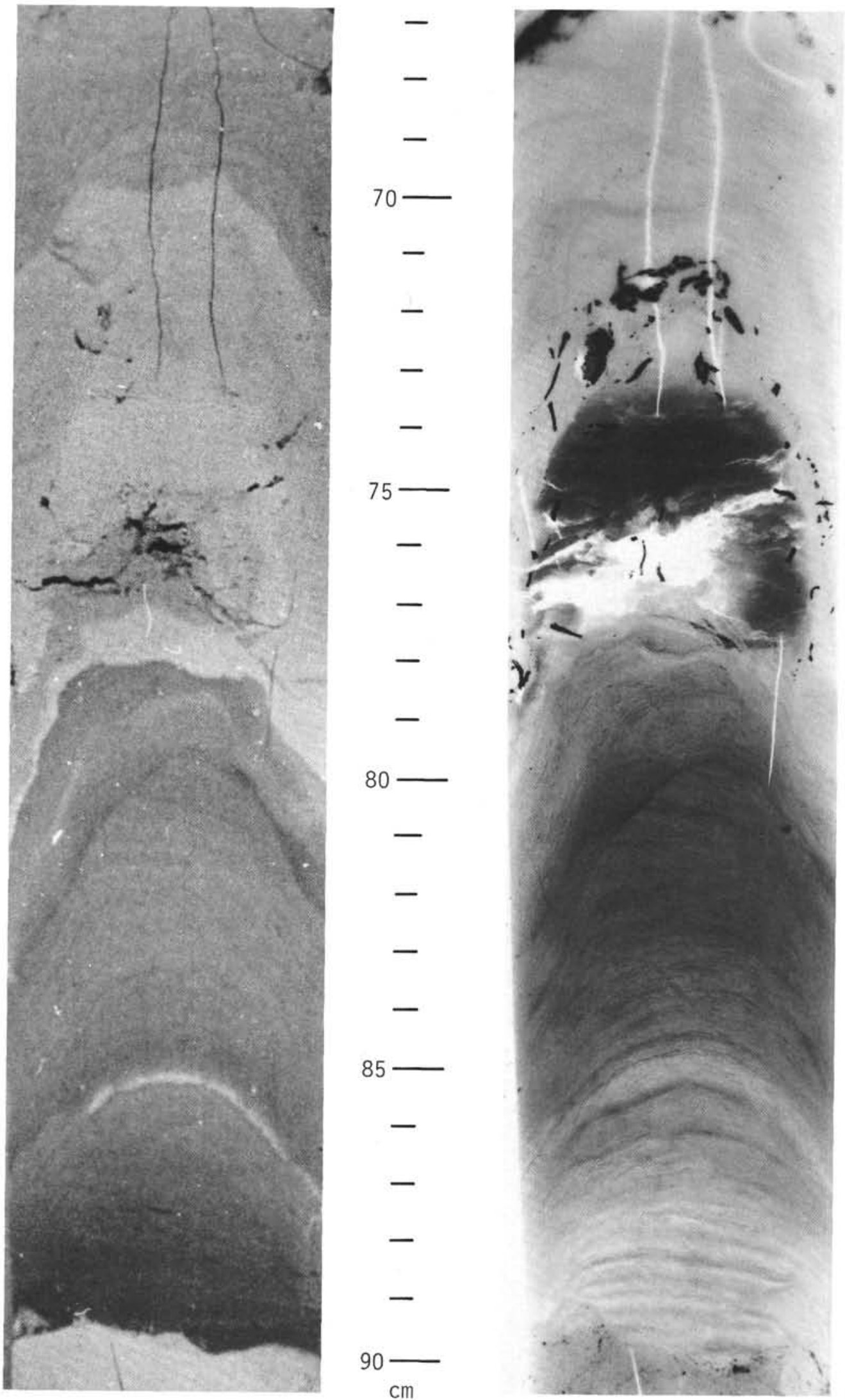

Figure 3. Photograph and print of radiograph from a sediment slice from Sample 299$2-6,67-90 \mathrm{~cm}$. 


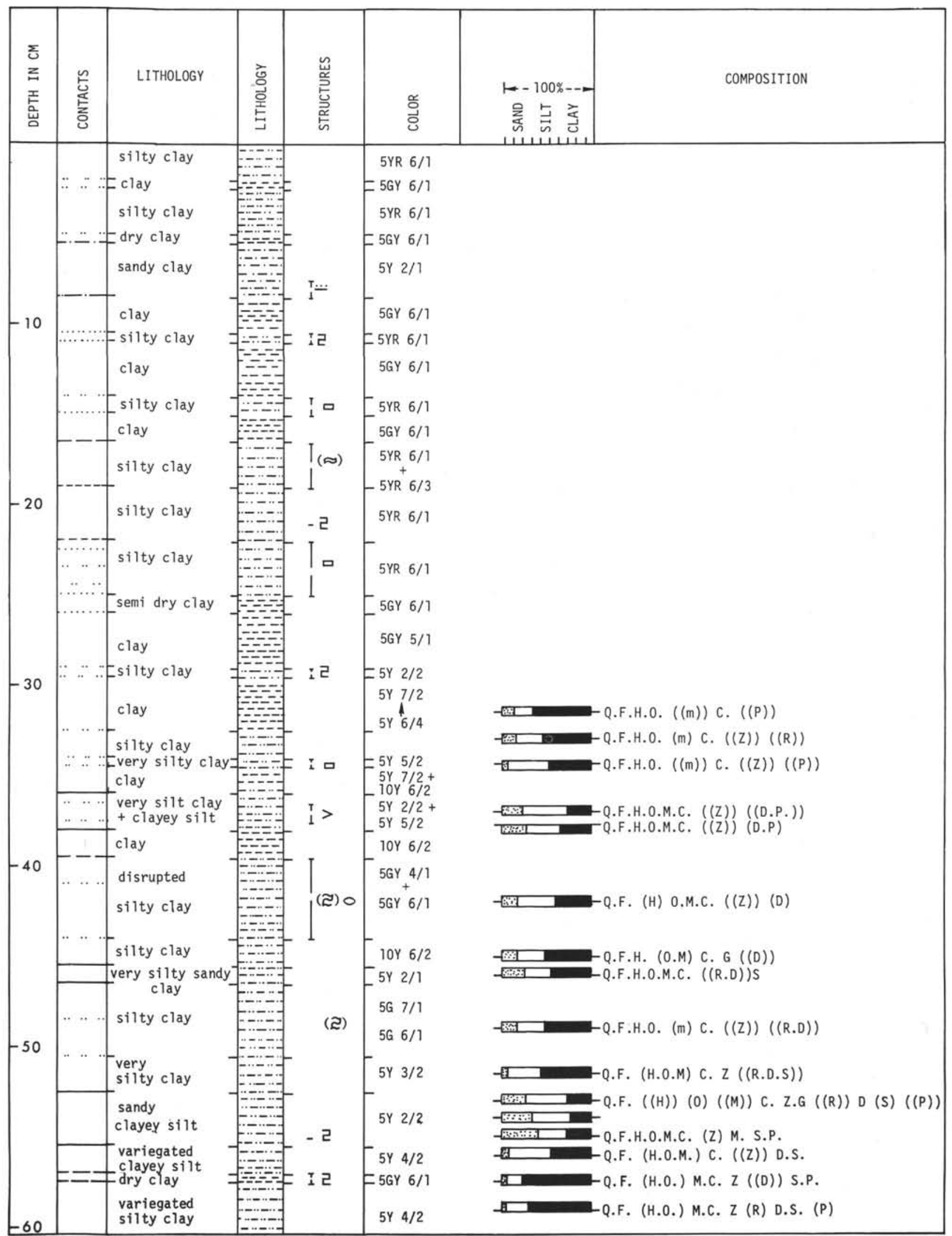

Figure 4. Semigraphical representation of the major part of Core 1, Section 1. The lithological and structural data come from core, photograph, and radiograph observations; the textural and semiquantitative compositional data from smear slides. 


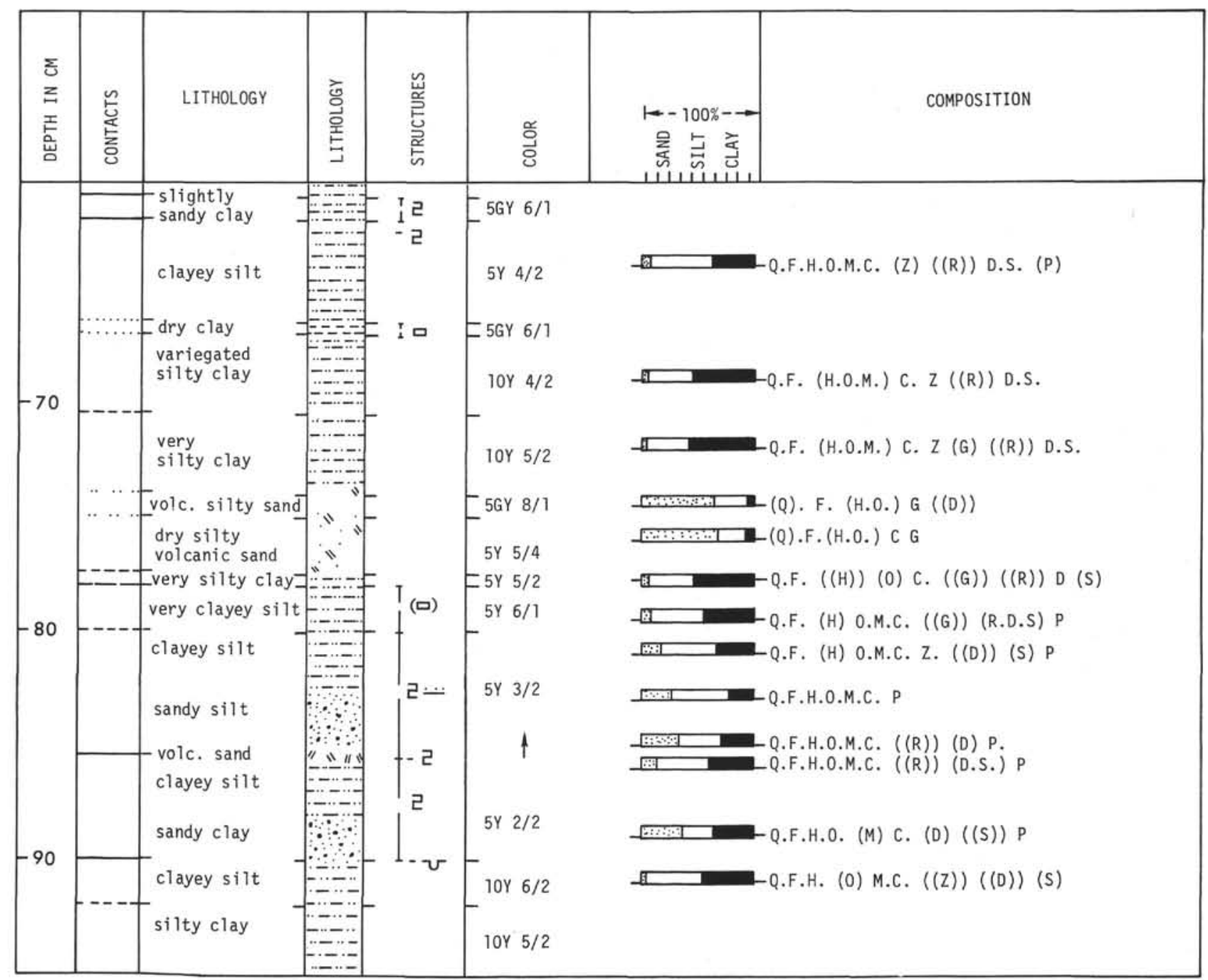

Figure 4. (Continued).

cases at least half of the fan area is covered with overbank deposits. The various subenvironments gradually change laterally into each other. Channel shifting is the reason for finding the same complexity in a vertical direction as is observed in a horizontal sense. Major channels may consist of a complex of small channels with small levees, meandering within a broader valley as can be observed on the Mississippi Cone (Bouma, 1973).

Occasionally small foreset bedding could be seen in some core sections. Together with the upward decrease in grain size, an increase in planktonic fossils can be observed in some cases. However, not enough data are available to see if this is a general trend. It is possible that the uppermost clay in the model (Table 1) is high in pelagic sediment.

The sedimentary model described from the upper 76 meters is considered to represent outer levee and proximal (adjacent to the levee) deposits. Cores from deeper levels cannot be compared completely to this model, and some parts seem to be quite different. These variations are considered to represent deposits being further outside the channel area (real overbank deposits), or more
TABLE 1

Possible Sedimentary Cycle as Observed in the Upper 76 Meters of Site 299, Sea of Japan

\begin{tabular}{|c|c|c|}
\hline Position & Lithology & Color \\
\hline Top & $\begin{array}{l}\text { Clay } \\
\text { Very slightly silty "dry" clay } \\
\text { Slightly silty clay } \\
\text { Very silty clay } \\
\text { Sandy-silty clay }\end{array}$ & $\begin{array}{l}\text { Light green gray } \\
\text { Dusky green } \\
\text { Greenish gray } \\
\text { Olive gray } \\
\text { Light olive black }\end{array}$ \\
\hline Bottom & Clayey sand with lamination & $\begin{array}{l}\text { Olive black or light } \\
\text { brownish gray }\end{array}$ \\
\hline
\end{tabular}

Note: Contracts between divisions normally are vague to transitional. The bottom division, especially when the color is light brownish gray, contains thin parallel lamination and rather distinct micrograded bedding.

inside than the model represents, such as outer channel and inner levee environments. A comparison to studies in the literature indicates that the deposits should not be interpreted as distal-like turbidites. However the possibility should not be ignored that some small turbidity currents deposited their load within the fan area. 
In such cases these currents moved under low-flowregime conditions, and their depositional flow characteristics do not vary much from bedloadsuspension type transport that may be more normal in the channels.

Kaseno (1971) recognized 12 distinct phases in the stratigraphic records of land geology starting with the formation of small nonmarine basins during the earliest Miocene. This was followed by volcanism and by marine invasion during early middle miocene. Deepening of basins (late middle Miocene) was succeeded by upheaval (late Miocene), transgression of cold waters (late Pliocene), brackish and lake deposits in relic basins (earliest Pleistocene), and intense folding and block movements during early Pleistocene. Lowering of sea level and valley cutting took place during the latest Pleistocene which is followed by the Holocene rise in sea level. The Toyama Trough thus can be considered a young feature. Site 299 fossils indicate: late Pleistocene to Holocene (Core 8); late Pleistocene (Core 9 to Core 15 , Section 2) and early Pleistocene (Core 15 , Section 5 to Core $30, \mathrm{CC})$. These ages may indicate that the marine events are slightly older than Kaseno (1971) presented for the island stratigraphy, or that displacement of fossils occurred allowing his series of stratigraphic events to coincide rather well with the offshore data.

\section{REFERENCES}

Bouma, A. H., 1969. Methods for the study of sedimentary structures: New York (John Wiley \& Sons), 458 p. 1972. Recent and ancient turbidites and contourites: Gulf Coast Assoc. Geol. Soc. Trans., v. 22, p. 205-221.

1973. Leveed-channel deposits, turbidites, and contourites in deeper part of Gulf of Mexico: Gulf Coast Assoc. Geol. Soc. Trans., v. 23, p. 368-376.
Bouma, A. H. and Hollister, D. C., 1973. Deep ocean basin sedimentation. Short course notes on turbidites and deepwater sedimentation, SEPM Pacific Section, Anaheim, Middleton, G. V. and Bouma, A. H. (co-chairmen), p. $79-$ 118.

Chmelik, F. B., 1967. Electro-osmotic core cutting: Marine Geol., v. 5, p. 321-325.

Hilde, T. W. C. and Wageman, J. M., 1973. Structure and origin of the Japan Sea. In Coleman, P. J. (Ed.), The western Pacific: island arcs, marginal seas, geochemistry: New York (Crane-Russak Co.), p. 415-434.

Hilde, T. W. C., Wageman, J. M., and Hammond, W. T., 1969. Sea of Japan structure from seismic reflection data: EOS, Am. Geophys. Union Trans. (1969 meeting-abstract), v. 50, p. 208.

Kaseno, Y., 1971. Cenozoic history of the Japan sea coast region of Japan with reference to the development of the Japan Sea: Kanazawa Univ., Japan Sea Res. Inst. Bull. 3, p. 1-4 (in Japanese and English).

1972. Geological features of the Japan Sea floor: a review of recent studies: Pacific Geol., v. 4, p. 91-111.

Ludwig, W. J., Murauchi, S., and Houtz, R. E., in press. Sediments and structure of the Japan Sea: Geophys. Res.

Nelson, C. H. and Kulm, L. D., 1973. Submarine fans and deep-sea channels. Short course notes on turbidites and deep-water sedimentation, SEPM Pacific Section, Anaheim, Middleton, G. V. and Bouma, A. H. (cochairmen), p. 39-78.

Niino, H., 1952. The bottom character of the banks and submarine valleys on and around the continental shelf of the Japanese Islands: Tokyo Univ. Fish., v. 38(3), p. 391-410.

Piper, D. J. W., 1973. The sedimentology of silt turbidites from the Gulf of Alaska. In Kulm, L. D., von Huene, R., et al., Initial Reports of the Deep Sea Drilling Project, Volume 18: Washington (U.S. Government Printing Office), p. 847-867.

Shepard, F. P. and Dill, R. F., 1966. Submarine canyons and other sea valleys: New York (Rand McNally), 381 p.

Terada, T., 1934. On bathymetrical features of the Japan Sea: Earthquake Res. Inst. Bull., Tokyo Univ., v. 12(4), p. 650-656. 